\title{
ESTIMATED DOMESTIC, IRRIGATION, AND INDUSTRIAL WATER USE IN WASHINGTON, 2000
}

\author{
By R.C. Lane
}

Since 1950, the U.S. Geological Survey has published a series of Circulars and other reports on the estimated use of water in the United States at 5-year intervals. This report presents State, regional, and county estimates of the amount of water used for domestic, irrigation, and industrial purposes in the State of Washington during the year 2000. Domestic water use was estimated to be 674 million gallons per day and the per-capita rate, 114 gallons per day. Crop-irrigation water use was estimated to be 3,005 million gallons per day and the application rate, 2.2 acre-feet per acre per year, or feet per year. Golf-course irrigation water use was estimated to be 23.6 million gallons per day and the application rate, 1.4 feet per year. Industrial water use was estimated to be 681 million gallons per day. Historically, these core categories account for about 92 percent of the estimated offstream water used in Washington.

\section{INTRODUCTION}

Water use, in the broadest sense, pertains to the interaction of human activity with the hydrologic cycle. Water use can be divided into two types, offstream and instream use. Offstream use is withdrawal or diversion of water from a ground- or surface-water source for a specific purpose. Instream use is the use of water that remains in the ground- or surface-water source. Quantitative estimates for most instream uses are undetermined, but are important because such uses compete with offstream uses and affect the quality and quantity of water resources. As used in this report, water use refers to the offstream use of water for domestic, irrigation, or industrial purposes.

Water use in Washington has evolved in the past century from meager domestic and stock water needs to the current complex requirements of domestic-water users, large irrigation projects, industrial plants, and numerous other uses such as fish habitat and recreational activities. Although advances have been made in the ability to control, divert, and develop water supplies, little effort has gone into keeping accurate accounts of the actual amounts of water being used. With increasing competition for water (especially during periods of drought), water-use information is of considerable value in determining water availability and in making sound resource-management decisions. Although the State of Washington has begun to collect water-use information in selected basins, there is currently no statewide program requiring the reporting of water-use information to the State.

Since 1950, the U.S. Geological Survey (USGS) has published a series of Circulars and other reports on the estimated use of water in the United States at 5-year intervals (see entries under U.S. Geological Survey in "Selected References"). These reports contain State-level estimates of the amount of public- and self-supplied water used for offstream commercial, domestic, industrial, irrigation, livestock, mining, power generation, and other purposes. Between 1985 and 1995, the core categories of domestic, irrigation, and industrial water use accounted for about 92 percent of the estimated offstream water use in Washington (U.S. Geological Survey, 1997a,b,c). The remaining 8 percent included public- and self-supplied water used for commercial, livestock, mining, power generation, and other uses.

\section{Purpose and Scope}

This report presents estimates of the amount water used for offstream domestic, crop and golf-course irrigation, and industrial purposes in the State of Washington during the year 2000, and describes the methods and sources used to prepare the estimates.

\section{Description of Study Area}

The north-south-trending Cascade Range and the prevailing wind patterns divide Washington State into two regions of distinctly different climate (Dion, 1985; Williams, 1986). Western Washington has a predominantly marine climate with cool, dry summers and mild, wet winters. Precipitation averages about $70 \mathrm{in} / \mathrm{yr}$ (inches per year), but ranges from less than 20 in/yr to about $200 \mathrm{in} / \mathrm{yr}$. Evaporation ranges from 20 to $25 \mathrm{in} / \mathrm{yr}$, and generally is less than precipitation. Eastern Washington has characteristics of both continental and marine climates, with hot, dry summers and cold, wet winters. Precipitation averages about $20 \mathrm{in} / \mathrm{yr}$, but ranges from less than $7 \mathrm{in} / \mathrm{yr}$ to about $40 \mathrm{in} / \mathrm{yr}$. Evaporation ranges from 25 to $45 \mathrm{in} / \mathrm{yr}$, and generally exceeds precipitation. 


\section{DOMESTIC WATER USE}

Domestic water use in Washington in the year 2000 was estimated to be $674 \mathrm{Mgal} / \mathrm{d}$ (million gallons per day; table 1).

Public water-supply systems delivered 81 percent (549 Mgal/ d) of the total domestic water use. Self-supplied withdrawals of ground water accounted for almost all of the remaining 19 percent (125 Mgal/d) of the total domestic use (table 1). The counties with the largest domestic use were (in descending order of use) King, Spokane, Pierce, Snohomish, Yakima, Clark, Thurston, and Kitsap Counties (fig. 1). These eight counties accounted for 73 percent $(490 \mathrm{Mgal} / \mathrm{d}$ ) of the total domestic water use in Washington. The per-capita domestic water use rate for the State was estimated to be $114 \mathrm{gal} / \mathrm{d}$ (gallons per day). The estimated per-capita rates for the 39 counties in Washington ranged from 87 to $238 \mathrm{gal} / \mathrm{d}$ (table 1; fig. 2).

Domestic water use in western Washington was estimated to be $445 \mathrm{Mgal} / \mathrm{d}$, or 66 percent of the total domestic water use in the State. Public water-supply systems delivered 83 percent

\section{How large is a million gallons per day?} A million gallons per day as a rate of flow of water is equal to $133,680.56$ cubic feet per day, or 1.5472 cubic feet per second, or 3.0689 acre-feet per day. A flow of 1 million gallons per day for 1 year equals 1,120 acre-feet (365 million gallons).

(371 Mgal/d) of the regional total. Self-supplied withdrawals of ground water accounted for the remaining 17 percent (74 $\mathrm{Mgal} / \mathrm{d}$ ) of the regional use. The western Washington counties with the largest domestic use were King, Pierce, Snohomish, and Clark Counties. These four counties accounted for 87 percent $(388 \mathrm{Mgal} / \mathrm{d})$ of the regional use. The per-capita domestic water-use rate for western Washington was estimated to be $97 \mathrm{gal} / \mathrm{d}$. The estimated per-capita rates for the 19 counties in western Washington ranged from 87 to $158 \mathrm{gal} / \mathrm{d}$.

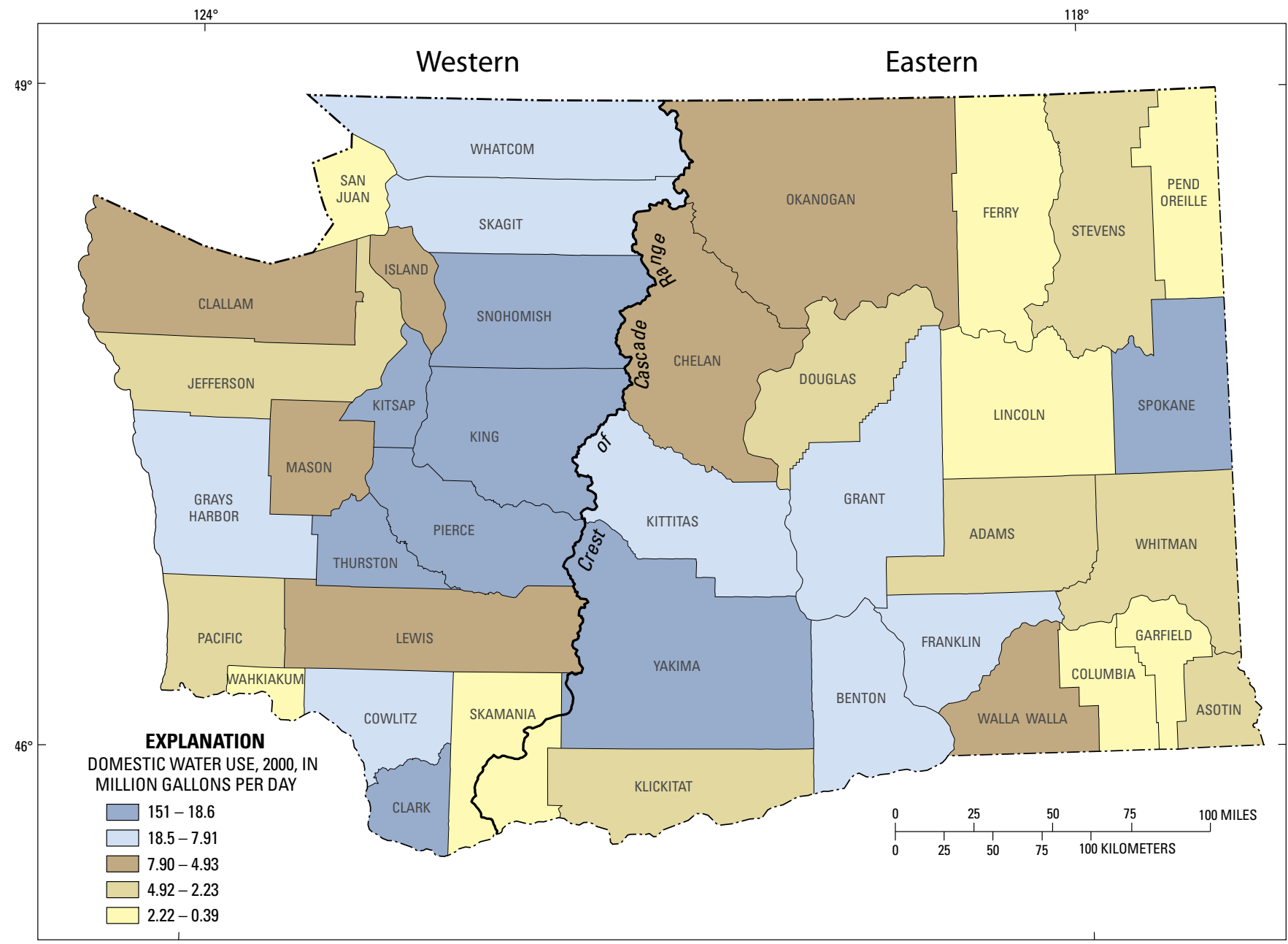

Figure 1. Estimated domestic water use in Washington, 2000. 
Table 1. Estimated domestic water use in Washington by county and source, 2000

[Values may not add up to totals because of independent rounding; Total domestic: Per capita, values are total withdrawals + deliveries divided by population served; Abbreviations: Mgal/d, million gallons per day; gal/d, gallons per day]

\begin{tabular}{|c|c|c|c|c|c|c|c|}
\hline \multirow[b]{2}{*}{ County } & \multicolumn{2}{|c|}{ Self supplied } & \multicolumn{2}{|c|}{ Public supplied } & \multicolumn{3}{|c|}{ Total domestic } \\
\hline & $\begin{array}{c}\text { Population } \\
\text { served } \\
\text { (thousands) }\end{array}$ & $\begin{array}{l}\text { Ground water } \\
\text { (Mgal/d) }\end{array}$ & $\begin{array}{c}\text { Population } \\
\text { served } \\
\text { (thousands) }\end{array}$ & $\begin{array}{l}\text { Water } \\
\text { (Mgal/d) }\end{array}$ & $\begin{array}{c}\text { Population } \\
\text { served } \\
\text { (thousands) }\end{array}$ & $\begin{array}{c}\text { Total } \\
\text { water use } \\
\text { (Mgal/d) }\end{array}$ & $\begin{array}{c}\text { Per capita } \\
\text { water use } \\
\text { (gal/d) }\end{array}$ \\
\hline Adams & 5.25 & 1.31 & 11.2 & 2.48 & 16.40 & 3.79 & 231 \\
\hline Asotin & 1.31 & .21 & 19.2 & 3.68 & 20.60 & 3.89 & 189 \\
\hline Benton & 28.6 & 3.32 & 114 & 13.1 & 142.00 & 16.4 & 115 \\
\hline Chelan & 16.8 & 2.00 & 49.8 & 5.87 & 66.60 & 7.87 & 118 \\
\hline Clallam & 13.7 & 1.41 & 50.8 & 5.06 & 64.50 & 6.47 & 100 \\
\hline Clark & 92.0 & 7.73 & 253 & 28.1 & 345.00 & 35.8 & 104 \\
\hline Columbia & 1.33 & .22 & 2.73 & .52 & 4.06 & .74 & 182 \\
\hline Cowlitz & 23.4 & 2.69 & 69.5 & 8.00 & 93.00 & 10.7 & 115 \\
\hline Douglas & 3.76 & .53 & 28.8 & 3.12 & 32.60 & 3.65 & 112 \\
\hline Ferry & 4.38 & ${ }^{1} .66$ & 2.88 & .36 & 7.26 & 1.02 & 141 \\
\hline Franklin & 10.5 & 2.21 & 38.9 & 8.10 & 49.40 & 10.3 & 209 \\
\hline Garfield & .93 & .15 & 1.47 & .28 & 2.40 & .43 & 179 \\
\hline Grant & 25.1 & 5.30 & 49.6 & 9.88 & 74.70 & 15.2 & 203 \\
\hline Grays Harbor & 11.9 & 1.80 & 55.3 & 8.31 & 67.20 & 10.1 & 150 \\
\hline Island & 8.82 & 1.03 & 62.7 & 5.39 & 71.60 & 6.42 & 90 \\
\hline Jefferson & 6.44 & .66 & 19.5 & 1.97 & 26.00 & 2.63 & 101 \\
\hline King & 144 & 16.0 & 1,595 & 135 & $1,735.00$ & 151 & 87 \\
\hline Kitsap & 41.4 & 4.43 & 191 & 16.2 & 232.40 & 20.6 & 89 \\
\hline Kittitas & 11.7 & 1.39 & 21.7 & 6.55 & 33.40 & 7.94 & 238 \\
\hline Klickitat & 7.43 & .94 & 11.7 & 2.07 & 19.20 & 3.01 & 157 \\
\hline Lewis & 34.1 & 3.41 & 34.5 & 4.30 & 68.60 & 7.71 & 112 \\
\hline Lincoln & 3.86 & .63 & 6.32 & 1.19 & 10.20 & 1.82 & 178 \\
\hline Mason & 16.9 & 1.86 & 32.5 & 3.59 & 49.40 & 5.45 & 110 \\
\hline Okanogan & 18.5 & 3.74 & 21.1 & 4.06 & 39.60 & 7.80 & 197 \\
\hline Pacific & 4.73 & .83 & 16.3 & 2.48 & 21.00 & 3.31 & 158 \\
\hline Pend Oreille & 6.34 & .70 & 5.39 & .53 & 11.73 & 1.23 & 105 \\
\hline Pierce & 26.0 & 3.06 & 675 & 63.8 & 701.00 & 66.9 & 95 \\
\hline San Juan & 6.80 & .78 & 7.28 & .66 & 14.10 & 1.44 & 102 \\
\hline Skagit & 33.9 & 4.23 & 69.1 & 8.57 & 103.00 & 12.8 & 124 \\
\hline Skamania & 4.14 & .41 & 5.73 & .56 & 9.87 & .97 & 98 \\
\hline Snohomish & 103 & 10.6 & 504 & 50.1 & 606.00 & 60.7 & 100 \\
\hline Spokane & 49.3 & 11.7 & 369 & 79.0 & 418.00 & 90.7 & 217 \\
\hline Stevens & 16.7 & 1.85 & 23.4 & 2.55 & 40.10 & 4.40 & 110 \\
\hline Thurston & 70.9 & 8.65 & 136 & 16.8 & 207.00 & 25.5 & 123 \\
\hline Wahkiakum & .90 & .09 & 2.92 & .30 & 3.82 & .39 & 102 \\
\hline Walla Walla & 8.66 & 1.06 & 46.5 & 5.40 & 55.20 & 6.46 & 117 \\
\hline Whatcom & 35.4 & 3.93 & 131 & 12.0 & 167.00 & 15.9 & 95 \\
\hline Whitman & 5.53 & .90 & 35.2 & 3.24 & 40.70 & 4.14 & 102 \\
\hline Yakima & 89.4 & 12.7 & 133 & 25.7 & 223.00 & 38.4 & 172 \\
\hline State & 994 & ${ }^{1} 125$ & 4,905 & 549 & $5,890.00$ & 674 & 114 \\
\hline
\end{tabular}

${ }^{1}$ Includes 0.02 million gallons per day surface-water withdrawal. 


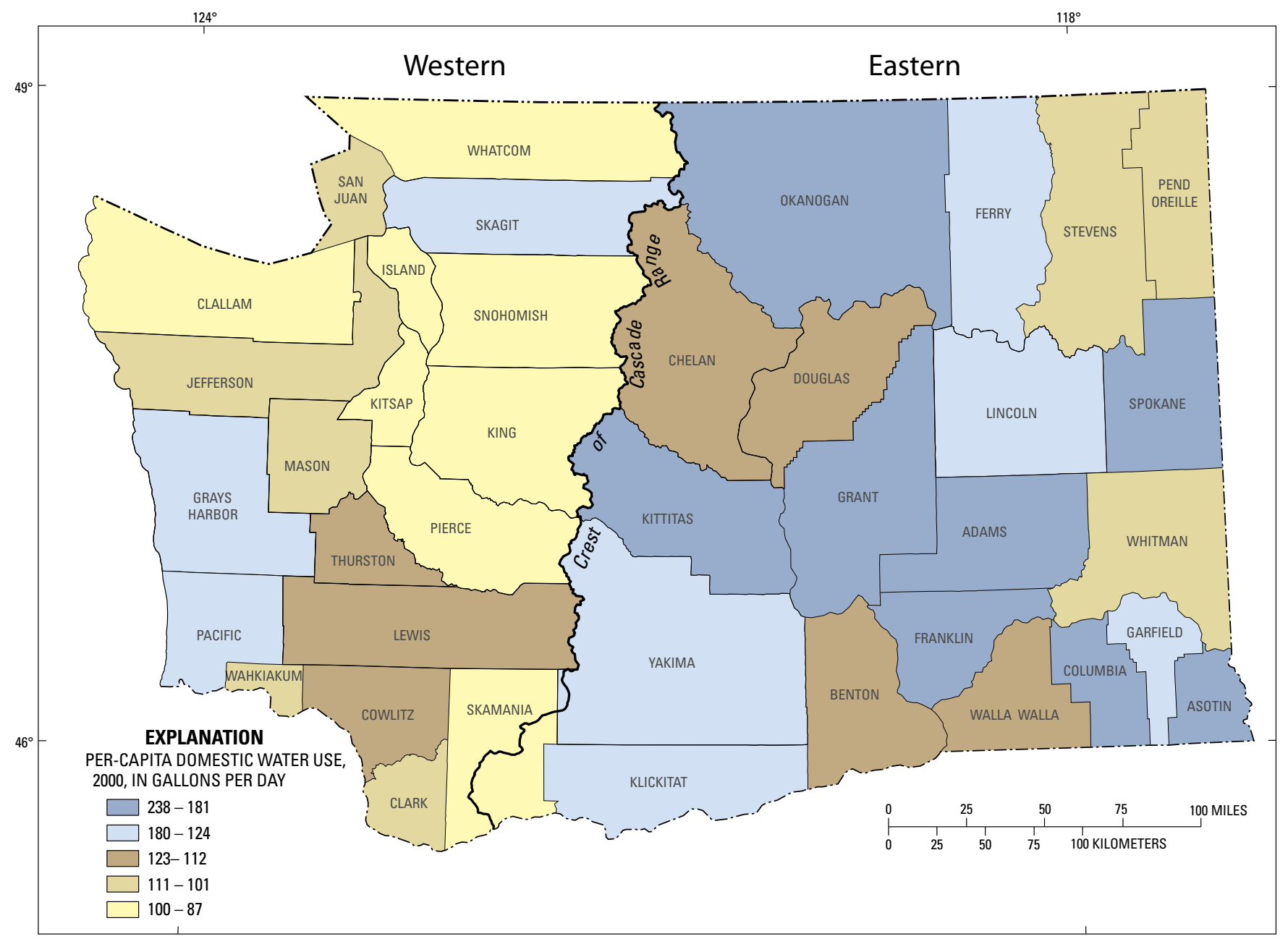

Figure 2. Estimated per-capita domestic water use in Washington, 2000.

Domestic water use in eastern Washington was estimated to be $229 \mathrm{Mgal} / \mathrm{d}$, or 34 percent of the total domestic water use in the State. Public water-supply systems delivered 77 percent (179 Mgal/d) of the regional total. Self-supplied withdrawals of ground water accounted for almost all of the remaining 23 percent $(52 \mathrm{Mgal} / \mathrm{d})$ of the regional total. The eastern Washington counties with the largest domestic use were Spokane, Yakima, Benton, and Grant Counties. These four counties accounted for 71 percent $(163 \mathrm{Mgal} / \mathrm{d})$ of the regional use. The per-capita domestic water-use rate for eastern Washington was estimated to be $175 \mathrm{gal} / \mathrm{d}$. The estimated per-capita rates for the 20 eastern Washington counties ranged from 102 to $238 \mathrm{gal} / \mathrm{d}$.

The estimates of public-supplied water use are based on data from the Washington State Department of Health (WDOH), the U.S. Census Bureau, and withdrawal and use information collected by the USGS during an inventory of selected public water-supply systems. A list of all registered public water-supply systems in Washington was obtained from the WDOH on-line database (Washington State Department of Health, 2001). The database contains the names, locations, service populations, and other data for all 16,677 registered public-water systems in the State. The database does not, however, contain information on water withdrawals and use.

The USGS collected withdrawal and usage data from 178 (7.5 percent) of the 2,340 registered Class A Systems. The selected systems accounted for 51 percent of the total public-supplied population. The criteria for selecting supply systems were to provide spatial coverage of each county in the State and to include a representative mix of the municipal, non-municipal, or other types of public-supply systems in the individual counties.

The withdrawal and use data from the inventoried systems in each county were used to calculate domestic per-capita use rates for the non-inventoried systems in that county. Each noninventoried system was assigned a per-capita rate based on the type of system, and that rate was multiplied by the system's service population to produce a system-level estimate of domestic water use. These system-level estimates and service populations were summed to produce the county-level estimates of publicsupplied domestic water use, population served, and per-capita use of public-supplied water. 
Table 2. Estimated crop-irrigation water use in Washington by county and source, 2000

[Values may not add up to totals due to independent rounding; Application rate: Values are total withdrawals divided by thousands of acres irrigated]

\begin{tabular}{|c|c|c|c|c|c|c|c|c|}
\hline \multirow{2}{*}{ County } & \multicolumn{3}{|c|}{$\begin{array}{c}\text { Withdrawals } \\
\text { (million gallons per day) }\end{array}$} & \multicolumn{3}{|c|}{$\begin{array}{c}\text { Withdrawals } \\
\text { (thousand acre-feet per year) }\end{array}$} & \multirow{2}{*}{$\begin{array}{c}\text { Acres } \\
\text { irrigated } \\
\text { (thousand } \\
\text { acres) }\end{array}$} & \multirow{2}{*}{$\begin{array}{l}\text { Application } \\
\text { rate } \\
\text { (acre-feet per } \\
\text { acre per year) }\end{array}$} \\
\hline & $\begin{array}{l}\text { Ground } \\
\text { water }\end{array}$ & $\begin{array}{c}\text { Surface } \\
\text { water }\end{array}$ & Total & $\begin{array}{l}\text { Ground } \\
\text { water }\end{array}$ & $\begin{array}{c}\text { Surface } \\
\text { water }\end{array}$ & Total & & \\
\hline Adams & 107 & 79.7 & 187 & 120 & 89.2 & 209 & 135 & 1.6 \\
\hline Asotin & .03 & .17 & .20 & .03 & .19 & .22 & .30 & .7 \\
\hline Benton & 18.2 & 219 & 237 & 20.3 & 245 & 265 & 140 & 1.9 \\
\hline Chelan & 3.11 & 47.2 & 50.3 & 3.48 & 52.8 & 56.3 & 27.9 & 2.0 \\
\hline Clallam & .17 & 5.63 & 5.80 & .19 & 6.31 & 6.50 & 3.44 & 1.9 \\
\hline Clark & 3.52 & 1.21 & 4.73 & 3.94 & 1.35 & 5.29 & 3.50 & 1.5 \\
\hline Columbia & .28 & 4.03 & 4.31 & .31 & 4.51 & 4.82 & 3.26 & 1.5 \\
\hline Cowlitz & .00 & 3.21 & 3.21 & .00 & 3.60 & 3.60 & 2.95 & 1.2 \\
\hline Douglas & 3.06 & 21.4 & 24.5 & 3.43 & 24.00 & 27.4 & 19.3 & 1.4 \\
\hline Ferry & .80 & 3.69 & 4.49 & .90 & 4.13 & 5.03 & 4.26 & 1.2 \\
\hline Franklin & 120 & 317 & 437 & 135 & 355 & 490 & 201 & 2.5 \\
\hline Garfield & .03 & .48 & .51 & .03 & .54 & .57 & .63 & .9 \\
\hline Grant & 258 & 672 & 930 & 289 & 753 & 1,040 & 406 & 2.6 \\
\hline Grays Harbor & 1.96 & 1.11 & 3.07 & 2.20 & 1.24 & 3.44 & 2.80 & 1.3 \\
\hline Island & .78 & .12 & .90 & .87 & .13 & 1.00 & 1.26 & .8 \\
\hline Jefferson & .86 & .20 & 1.06 & .96 & .22 & 1.18 & .78 & 1.5 \\
\hline King & 2.15 & .63 & 2.78 & 2.41 & .71 & 3.12 & 3.00 & 1.1 \\
\hline Kitsap & .17 & .20 & .37 & .19 & .22 & .41 & .34 & 1.2 \\
\hline Kittitas & .00 & 199 & 199 & .00 & 223 & 223 & 69.2 & 3.2 \\
\hline Klickitat & 16.5 & 10.0 & 26.5 & 18.5 & 11.2 & 29.7 & 18.40 & 1.6 \\
\hline Lewis & 3.06 & 2.95 & 6.01 & 3.43 & 3.30 & 6.73 & 5.26 & 1.3 \\
\hline Lincoln & 27.8 & 8.09 & 35.90 & 31.2 & 9.06 & 40.3 & 43.7 & .9 \\
\hline Mason & .27 & .12 & .39 & .30 & .13 & .43 & .35 & 1.3 \\
\hline Okanogan & 19.8 & 52.8 & 72.6 & 22.2 & 59.1 & 81.3 & 43.50 & 1.9 \\
\hline Pacific & 1.14 & 2.12 & 3.26 & 1.28 & 2.37 & 3.65 & 3.07 & 1.2 \\
\hline Pend Oreille & .28 & .46 & .74 & .31 & .51 & .82 & 1.44 & .6 \\
\hline Pierce & 4.40 & 1.10 & 5.50 & 4.93 & 1.23 & 6.16 & 4.70 & 1.3 \\
\hline San Juan & .03 & .19 & .22 & .03 & .21 & .24 & .82 & .3 \\
\hline Skagit & 6.65 & 1.74 & 8.39 & 7.45 & 1.95 & 9.40 & 8.95 & 1.1 \\
\hline Skamania & .00 & .25 & .25 & .00 & .28 & .28 & .25 & 1.1 \\
\hline Snohomish & 1.84 & 1.22 & 3.06 & 2.06 & 1.37 & 3.43 & 3.81 & .9 \\
\hline Spokane & 8.06 & 1.10 & 9.16 & 9.03 & 1.23 & 10.3 & 9.77 & 1.1 \\
\hline Stevens & 1.53 & 8.00 & 9.53 & 1.71 & 8.96 & 10.7 & 9.12 & 1.2 \\
\hline Thurston & 4.62 & 1.54 & 6.16 & 5.18 & 1.72 & 6.90 & 5.07 & 1.4 \\
\hline Wahkiakum & .07 & .12 & .19 & .08 & .14 & .22 & .16 & 1.4 \\
\hline Walla Walla & 42.2 & 81.9 & 124 & 47.3 & 91.8 & 139 & 88.6 & 1.6 \\
\hline Whatcom & 18.2 & 5.07 & 23.3 & 20.4 & 5.68 & 26.1 & 23.5 & 1.1 \\
\hline Whitman & .63 & 2.17 & 2.80 & .71 & 2.43 & 3.14 & 4.99 & .6 \\
\hline Yakima & 62.1 & 507 & 569 & 69.5 & 568 & 638 & 253 & 2.5 \\
\hline State & 739 & 2,265 & 3,005 & 829 & 2,535 & 3,365 & 1,555 & 2.2 \\
\hline
\end{tabular}


The estimates of self-supplied domestic water use are based on the county-level domestic per-capita rates for public-supplied water use and the self-supplied population of each county. The self-supplied population of each county was estimated by subtracting the population served by Class A Systems (Washington State Department of Health, 2001) from the total population of the county (U.S. Department of Commerce, 2001). For the purposes of this report, the public-supplied domestic-use category includes only those people who are served by a Class A public water-supply system. The self-supplied domestic-use category includes those who are self-supplied and those who are served by a Class B public water-supply system. Statewide, some 4.90 million people are served by a Class A system. The remaining 0.99 million people are either self-supplied ( 0.89 million people) or are served by a Class B system.

\section{CROP-IRRIGATION WATER USE}

Crop-irrigation water use in Washington in the year 2000 was estimated to be 3,365 thousand acre-ft (acre-feet) of water (3,005 Mgal/d; table 2). Ground-water use accounted for 25 percent ( 829 thousand acre-ft), and surface-water use accounted for 75 percent $(2,535$ thousand acre- $\mathrm{ft})$ of the total use. The eight eastern Washington counties of Grant, Yakima, Franklin, Benton, Kittitas, Adams, Walla Walla, and Okanogan accounted for 92 percent (3,085 thousand acre-ft) of total cropirrigation water use in the State (fig. 3).

The crop-irrigation application rate for the State was estimated to be 2.2 (acre-ft/acre)/yr [ (acre-ft per acre per year, or feet per year (ft/yr)], and the county application rates ranged from 0.3 to $3.2 \mathrm{ft} / \mathrm{yr}$ (fig. 4). For western Washington the

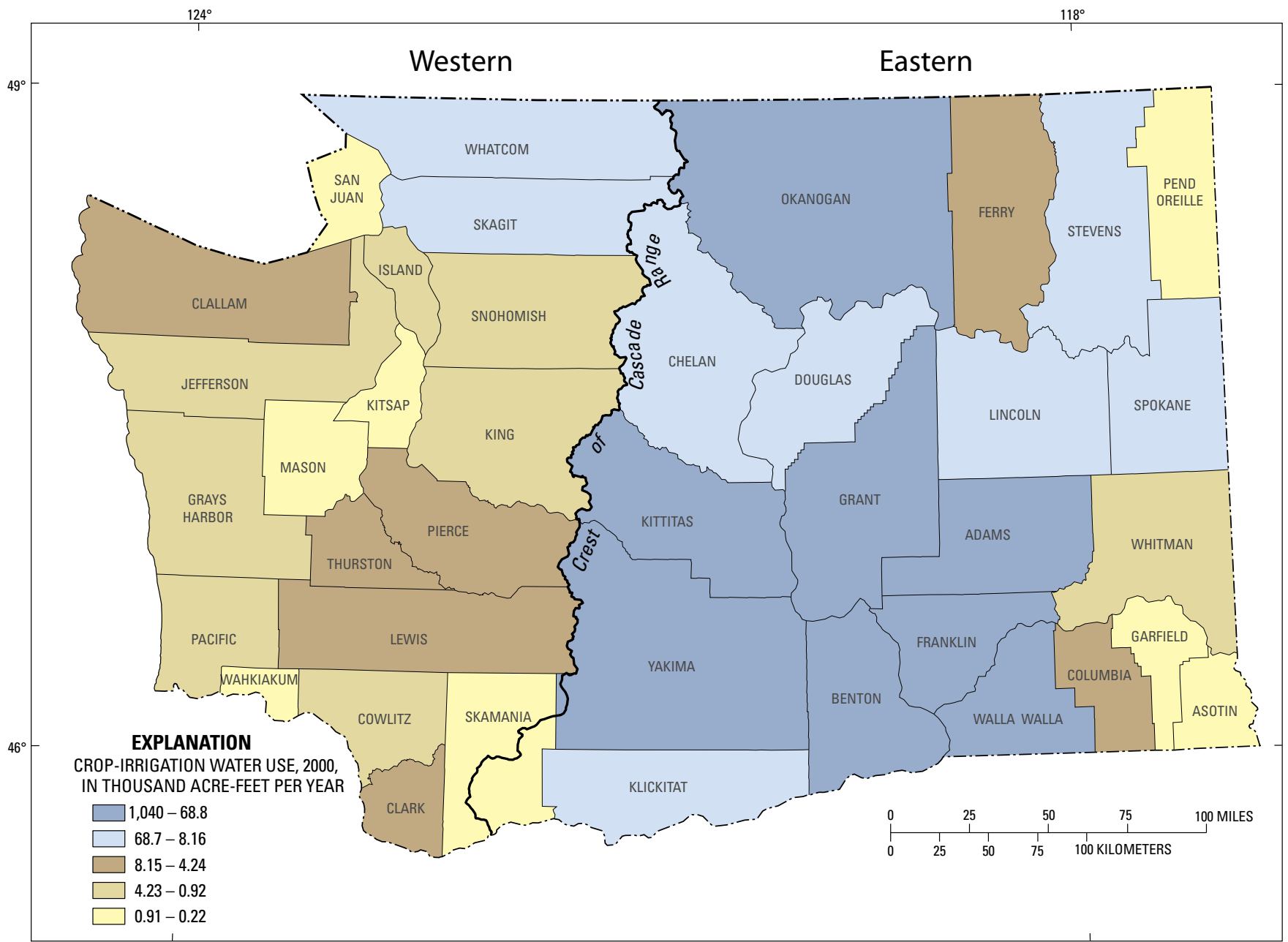

Figure 3. Estimated crop-irrigation water use in Washington, 2000. 


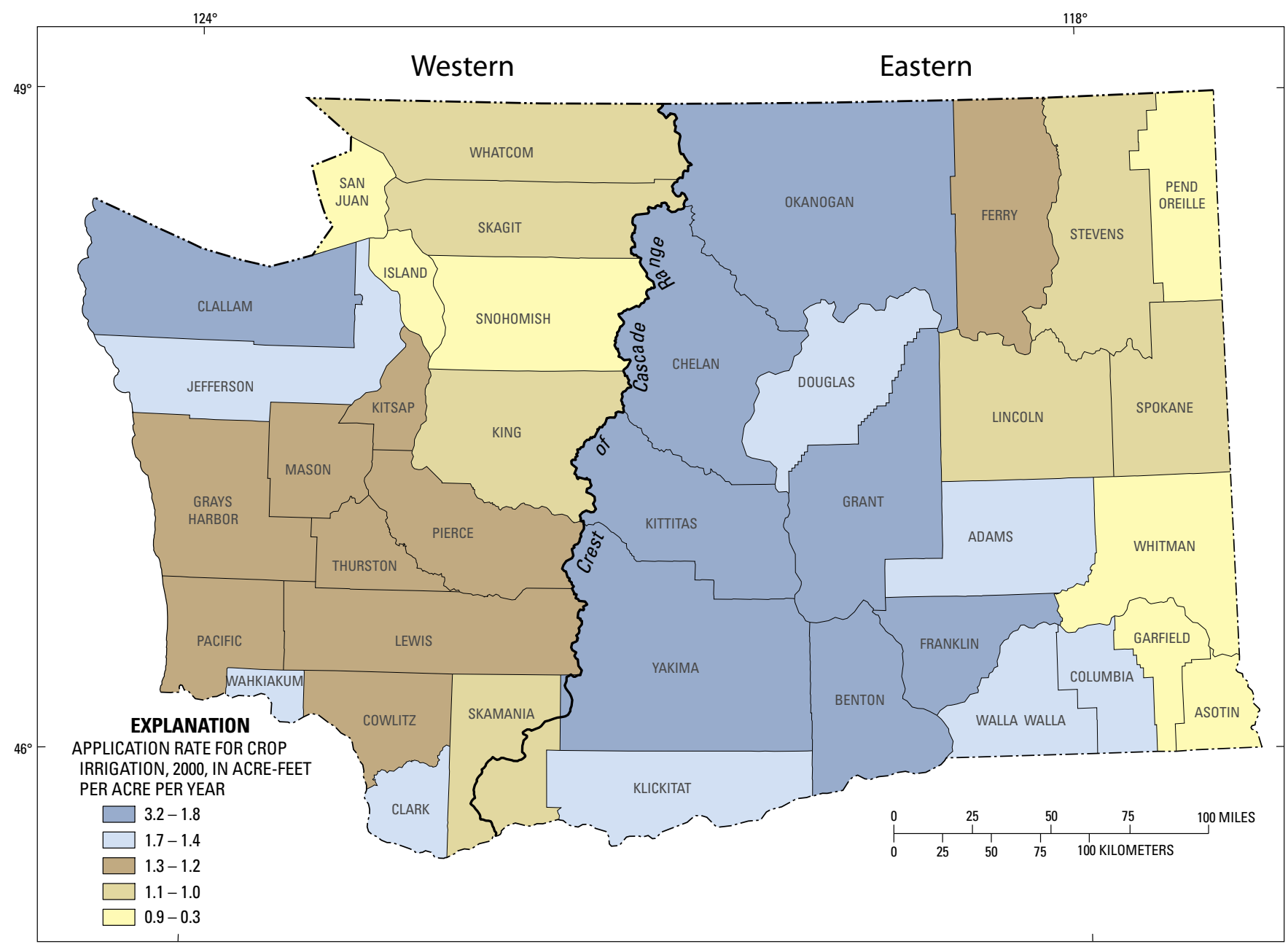

Figure 4. Estimated application rates for crop irrigation in Washington, 2000.

crop-irrigation application rate was estimated to be 1.2 $\mathrm{ft} / \mathrm{yr}$, and the county rates ranged from 0.3 to $1.9 \mathrm{ft} / \mathrm{yr}$. For eastern Washington the regional application rate was estimated to be $2.2 \mathrm{ft} / \mathrm{yr}$, and the county application rates ranged from 0.6 to $3.2 \mathrm{ft} / \mathrm{yr}$.

Acreage and application data for crop-irrigation water use were not available for the 2000 growing season. Therefore, acreage and application data for 1998 (U.S. Department of
Agriculture, 1998) were used to approximate conditions for the 2000 growing season. The State-level acreage data were disaggregated to the county level on the basis of data from the 1997 agricultural census (U.S. Department of Agriculture, 1997). The State-level application rate was disaggregated to the county level on the basis of data from the 1995 Washington water use data (U.S. Geological Survey, 1997c).

\section{Units of Measurement}

Water use is usually expressed as a rate; that is, a volume of water over a period of time. Common rates for water use are thousand gallons or 100 cubic feet, ccf (such as for a meter reading); gallons per minute, gpm (as in pumpage); gallons per day, gpd (as in use per person or per household); million gallons per day, Mgal/d (as in use per facility or per geographically or politically bounded area); billion gallons per day, bgd (as in a national total); or acre-feet, acre-ft (most commonly used for irrigation water use and in the western United States). 


\section{GOLF-COURSE IRRIGATION WATER USE}

Golf-course irrigation water use in Washington in the year 2000 was estimated to be 26.5 thousand acre- $\mathrm{ft}$ ( 23.6 $\mathrm{Mgal} / \mathrm{d}$; table 3). Ground-water use accounted for 23 percent (6.20 thousand acre-ft) and surface-water use accounted for 77 percent (20.3 thousand acre-ft) of the total use. The largest withdrawals for golf-course irrigation were in King, Pierce, Grant, Spokane, Whatcom, Yakima, Snohomish, and Benton Counties (fig. 5). These eight counties accounted for 61 percent (16.1 thousand acre-ft) of the total water used in Washington for golf-course irrigation. The golf-course irrigation application rate for the State was estimated to be $1.4 \mathrm{ft} / \mathrm{yr}$, and the county application rates ranged from 0.3 to $3.2 \mathrm{ft} / \mathrm{yr}$ (fig. 6).

Golf-course irrigation in western Washington was estimated to be 16.4 thousand acre-ft, or about 62 percent of the total State use. The largest withdrawals were in King, Pierce,
Whatcom, and Snohomish Counties. Withdrawals in these four counties amounted to 9.49 thousand acre-ft, or about 36 percent of the State total and 58 percent of the regional use. For western Washington, the golf-course irrigation application rate was estimated to be $1.2 \mathrm{ft} / \mathrm{yr}$, and the county rates ranged from 0.30 to $2.0 \mathrm{ft} / \mathrm{yr}$.

Golf-course irrigation in eastern Washington was estimated to be 10.1 thousand acre-ft, or about 38 percent of the total State use. The largest withdrawals were in Grant, Spokane, Yakima, and Benton Counties. Withdrawals in these four counties amounted to 6.60 thousand acre-ft, or about 25 percent of the State total and 82 percent of the regional use. For eastern Washington, the golf-course irrigation application rate was estimated to be $1.8 \mathrm{ft} / \mathrm{yr}$, and the county rates ranged from 0.6 to $3.2 \mathrm{ft} / \mathrm{yr}$.

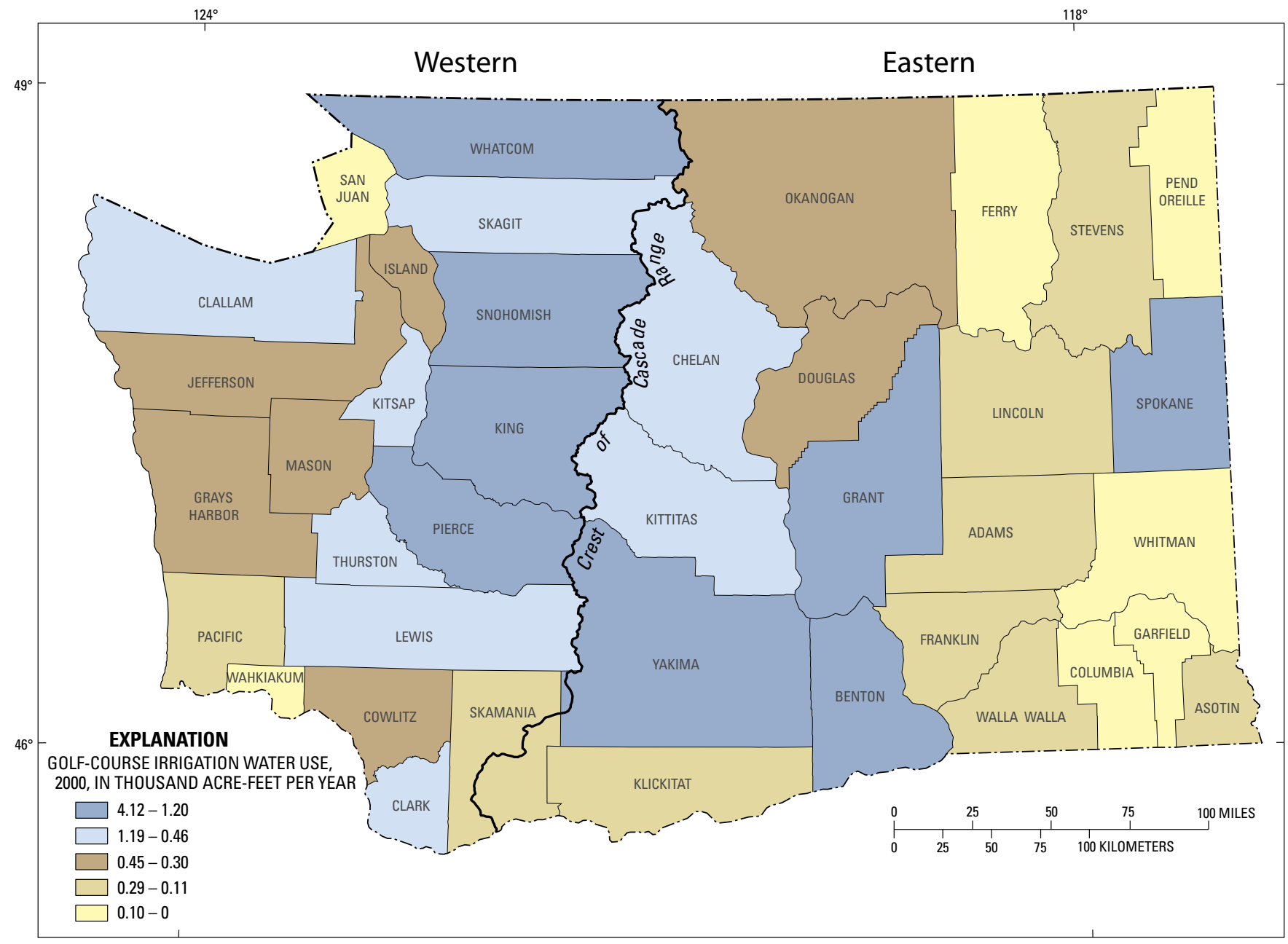

Figure 5. Estimated golf-course irrigation water use in Washington, 2000. 
Table 3. Estimated golf-course irrigation water use in Washington by county and source, 2000

[Values may not add up to totals due to independent rounding]

\begin{tabular}{|c|c|c|c|c|c|c|c|c|}
\hline \multirow{2}{*}{ County } & \multicolumn{3}{|c|}{$\begin{array}{c}\text { Water use } \\
\text { (million gallons per day) }\end{array}$} & \multicolumn{3}{|c|}{$\begin{array}{c}\text { Water use } \\
\text { (thousand acre-feet per year) }\end{array}$} & \multirow{2}{*}{$\begin{array}{l}\text { Acres irrigated } \\
\text { (thousand acres) }\end{array}$} & \multirow{2}{*}{$\begin{array}{l}\text { Application rate } \\
\text { (acre-feet per } \\
\text { acre per year) }\end{array}$} \\
\hline & $\begin{array}{l}\text { Ground } \\
\text { water }\end{array}$ & $\begin{array}{l}\text { Surface } \\
\text { water }\end{array}$ & $\begin{array}{l}\text { Total } \\
\text { water }\end{array}$ & $\begin{array}{l}\text { Ground } \\
\text { water }\end{array}$ & $\begin{array}{l}\text { Surface } \\
\text { water }\end{array}$ & $\begin{array}{l}\text { Total } \\
\text { water }\end{array}$ & & \\
\hline Adams & 0.03 & 0.08 & 0.11 & 0.03 & 0.09 & 0.12 & 0.08 & 1.5 \\
\hline Asotin & .01 & .10 & .11 & .01 & .11 & .12 & .16 & .8 \\
\hline Benton & .04 & 1.13 & 1.17 & .04 & 1.27 & 1.31 & .69 & 1.9 \\
\hline Chelan & .02 & .71 & .73 & .02 & .80 & .82 & .41 & 2.0 \\
\hline Clallam & .01 & .41 & .42 & .01 & .46 & .47 & .24 & 2.0 \\
\hline Clark & .30 & .61 & .91 & .34 & .68 & 1.02 & .65 & 1.6 \\
\hline Columbia & .00 & .05 & .05 & .00 & .06 & .06 & .04 & 1.5 \\
\hline Cowlitz & .00 & .39 & .39 & .00 & .44 & .44 & .36 & 1.2 \\
\hline Douglas & .02 & .29 & .31 & .02 & .33 & .35 & .24 & 1.5 \\
\hline Ferry & .00 & .04 & .04 & .00 & .04 & .04 & .04 & 1.0 \\
\hline Franklin & .02 & .15 & .17 & .02 & .17 & .19 & .08 & 2.4 \\
\hline Garfield & .00 & .04 & .04 & .00 & .04 & .04 & .04 & 1.0 \\
\hline Grant & .26 & 1.78 & 2.04 & .29 & 1.99 & 2.28 & .89 & 2.6 \\
\hline Grays Harbor & .09 & .22 & .31 & .10 & .25 & .35 & .28 & 1.3 \\
\hline Island & .14 & .21 & .35 & .16 & .23 & .39 & .49 & .8 \\
\hline Jefferson & .11 & .21 & .32 & .12 & .24 & .36 & .20 & 1.8 \\
\hline King & 1.26 & 2.42 & 3.68 & 1.41 & 2.71 & 4.12 & 3.73 & 1.1 \\
\hline Kitsap & .21 & .77 & .98 & .23 & .86 & 1.09 & .89 & 1.2 \\
\hline Kittitas & .00 & .46 & .46 & .00 & .52 & .52 & .16 & 3.2 \\
\hline Klickitat & .04 & .09 & .13 & .04 & .10 & .14 & .08 & 1.8 \\
\hline Lewis & .10 & .32 & .42 & .11 & .36 & .47 & .36 & 1.2 \\
\hline Lincoln & .06 & .12 & .18 & .07 & .13 & .20 & .20 & 1.0 \\
\hline Mason & .12 & .23 & .35 & .13 & .26 & .39 & .32 & 1.2 \\
\hline Okanogan & .04 & .29 & .33 & .05 & .33 & .38 & .20 & 1.9 \\
\hline Pacific & .02 & .11 & .13 & .02 & .12 & .14 & .12 & 1.2 \\
\hline Pend Oreille & .00 & .00 & .00 & .00 & .00 & .00 & .00 & 0 \\
\hline Pierce & .79 & 1.46 & 2.25 & .89 & 1.63 & 2.52 & 1.82 & 1.4 \\
\hline San Juan & .00 & .03 & .03 & .00 & .03 & .03 & .12 & .3 \\
\hline Skagit & .16 & .29 & .45 & .18 & .33 & .51 & .45 & 1.1 \\
\hline Skamania & .00 & .21 & .21 & .00 & .23 & .23 & .20 & 1.2 \\
\hline Snohomish & .35 & .91 & 1.26 & .39 & 1.02 & 1.41 & 1.54 & .9 \\
\hline Spokane & .49 & .92 & 1.41 & .55 & 1.03 & 1.58 & 1.26 & 1.3 \\
\hline Stevens & .01 & .12 & .13 & .01 & .13 & .14 & .12 & 1.2 \\
\hline Thurston & .29 & .56 & .85 & .33 & .63 & .96 & .69 & 1.4 \\
\hline Wahkiakum & .01 & .04 & .05 & .01 & .05 & .06 & .04 & 1.5 \\
\hline Walla Walla & .04 & .19 & .23 & .04 & .21 & .25 & .16 & 1.6 \\
\hline Whatcom & .45 & .84 & 1.29 & .50 & .94 & 1.44 & 1.22 & 1.2 \\
\hline Whitman & .01 & .07 & .08 & .01 & .08 & .09 & .15 & .6 \\
\hline Yakima & .06 & 1.21 & 1.27 & .07 & 1.36 & 1.43 & .57 & 2.5 \\
\hline State & 5.56 & 18.1 & 23.6 & 6.2 & 20.3 & 26.5 & 19.3 & 1.4 \\
\hline
\end{tabular}




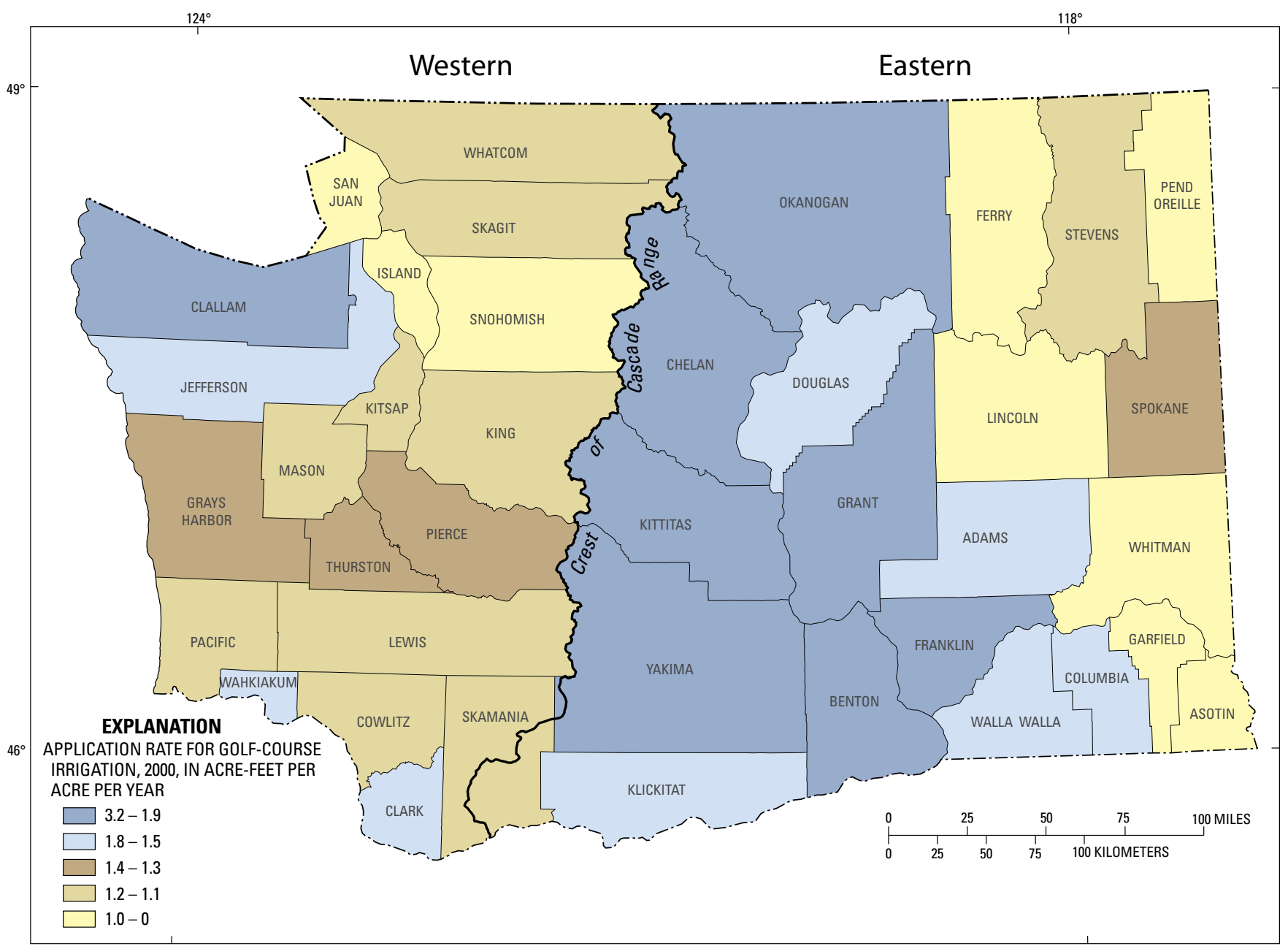

Figure 6. Estimated application rates for golf-course irrigation in Washington, 2000.

Information on the location and size (number of holes) of golf courses in Washington was obtained on the World Wide Web at the URLs www.worldgolf.com and www.golfcourse. com. The number of holes per course was aggregated to the county level and the irrigated acreage was estimated on the basis of 4.5 acres per hole (Richard L. Marella, U.S. Geological Survey, oral commun., 2001). County-level water use for golfcourse irrigation was estimated by multiplying the estimated acres per county by the estimated application rates from the crop-irrigation category.

\section{INDUSTRIAL WATER USE}

Industrial water use in Washington in the year 2000 was estimated to be $681 \mathrm{Mgal} / \mathrm{d}$ (table 4). Public water-supply systems delivered only 9 percent $(63.5 \mathrm{Mgal} / \mathrm{d})$ of the total industrial use. Self-supplied fresh ground water accounted for 20 percent (138 Mgal/d), self-supplied fresh surface water accounted for 64 percent (439 Mgal/d), and self-supplied saline surface water accounted for the remaining 7 percent (39.9 $\mathrm{Mgal} / \mathrm{d}$ ) of the total industrial use. The largest industrial withdrawals were in Cowlitz, Clark, Spokane, Snohomish, Pierce, Benton, Whatcom, and Walla Walla Counties (fig. 7). These eight counties accounted for 83 percent $(563 \mathrm{Mgal} / \mathrm{d})$ of the total industrial water use in Washington.

Industrial water use in western Washington was estimated to be $488 \mathrm{Mgal} / \mathrm{d}$, or 77 percent of the total State use. Public water-supply systems delivered 9 percent $(45.9 \mathrm{Mgal} / \mathrm{d})$ of the regional use. Self-supplied fresh ground water accounted for 20 percent ( $96.8 \mathrm{Mgal} / \mathrm{d})$, self-supplied fresh surface water accounted for 63 percent (305 Mgal/d), and self-supplied saline surface water accounted for 8 percent $(39.9 \mathrm{Mgal} / \mathrm{d})$. The largest industrial withdrawals in western Washington were in Cowlitz, Clark, Snohomish, and Pierce Counties. These four counties accounted for 70 percent (343 Mgal/d) of the regional industrial use and 50 percent of the State total industrial water use. 
Table 4. Estimated industrial water use in Washington, by county and source, 2000

[Values may not add up to totals due to independent rounding; Abbreviations: Mgal/d, million gallons per day]

\begin{tabular}{|c|c|c|c|c|c|c|c|}
\hline \multirow{3}{*}{ County } & \multicolumn{5}{|c|}{ Self-supplied withdrawals (Mgal/d) } & \multirow{3}{*}{$\begin{array}{c}\text { Public } \\
\text { supplied } \\
\text { deliveries } \\
\text { (Mgal/d) }\end{array}$} & \multirow{3}{*}{$\begin{array}{c}\text { Total water } \\
\text { use } \\
\text { (Mgal/d) }\end{array}$} \\
\hline & \multirow{2}{*}{\begin{tabular}{|c|} 
Ground water \\
Fresh
\end{tabular}} & \multicolumn{2}{|c|}{ Surface water } & \multicolumn{2}{|c|}{ Total water } & & \\
\hline & & Fresh & Saline & $\begin{array}{l}\text { Total } \\
\text { Fresh }\end{array}$ & $\begin{array}{c}\text { Fresh + } \\
\text { saline }\end{array}$ & & \\
\hline Adams & 2.23 & 0.00 & 0.00 & 2.23 & 2.23 & 3.29 & 5.52 \\
\hline Asotin & .00 & .00 & .00 & .00 & .00 & .00 & .00 \\
\hline Benton & 9.76 & 65.3 & .00 & 75.1 & 75.1 & .00 & 75.1 \\
\hline Chelan & .00 & 14.5 & .00 & 14.5 & 14.5 & .12 & 14.6 \\
\hline Clallam & .02 & .01 & .00 & .03 & .03 & .15 & .18 \\
\hline Clark & 68.8 & 61.0 & .00 & 130 & 130 & 1.76 & 132 \\
\hline Columbia & .08 & .00 & .00 & .08 & .08 & .00 & .08 \\
\hline Cowlitz & .00 & 152 & .00 & 152 & 152 & .00 & 152 \\
\hline Douglas & 3.34 & .00 & .00 & 3.34 & 3.34 & .00 & 3.34 \\
\hline Ferry & .29 & .00 & .00 & .29 & .29 & .00 & .29 \\
\hline Franklin & 1.75 & .00 & .00 & 1.75 & 1.75 & .00 & 1.75 \\
\hline Garfield & .01 & .00 & .00 & .01 & .01 & .00 & .01 \\
\hline Grant & 3.21 & .00 & .00 & 3.21 & 3.21 & 4.42 & 7.63 \\
\hline Grays Harbor & 1.22 & .01 & 7.52 & 1.23 & 8.75 & .18 & 8.93 \\
\hline Island & .01 & .00 & .00 & .01 & .01 & .00 & .01 \\
\hline Jefferson & .00 & .00 & 6.94 & .00 & 6.94 & .00 & 6.94 \\
\hline King & 3.12 & 2.66 & .00 & 5.78 & 5.78 & 4.44 & 10.2 \\
\hline Kitsap & .02 & .07 & .00 & .09 & .09 & 2.75 & 2.84 \\
\hline Kittitas & 1.41 & .00 & .00 & 1.41 & 1.41 & .01 & 1.42 \\
\hline Klickitat & .00 & 2.78 & .00 & 2.78 & 2.78 & .00 & 2.78 \\
\hline Lewis & 3.07 & .00 & .00 & 3.07 & 3.07 & .31 & 3.38 \\
\hline Lincoln & .01 & .00 & .00 & .01 & .01 & .01 & 0.02 \\
\hline Mason & .41 & 9.75 & .00 & 10.2 & 10.2 & .00 & 10.2 \\
\hline Okanogan & 3.78 & .00 & .00 & 3.78 & 3.78 & .00 & 3.78 \\
\hline Pacific & .20 & .28 & .00 & .48 & .48 & .05 & .53 \\
\hline Pend Oreille & .00 & .92 & .00 & .92 & .92 & .00 & .92 \\
\hline Pierce & 12.9 & 4.74 & 25.4 & 17.6 & 43.0 & .80 & 43.8 \\
\hline San Juan & .39 & .00 & .00 & .39 & .39 & .01 & .40 \\
\hline Skagit & .01 & .02 & .00 & .03 & .03 & .25 & .28 \\
\hline Skamania & .00 & 11.3 & .00 & 11.3 & 11.3 & .01 & 11.3 \\
\hline Snohomish & 2.33 & 55.9 & .00 & 58.2 & 58.2 & .68 & 58.9 \\
\hline Spokane & 8.20 & 35.0 & .00 & 43.2 & 43.2 & 1.44 & 44.6 \\
\hline Stevens & .00 & .12 & .00 & .12 & .12 & .60 & .72 \\
\hline Thurston & 4.18 & .00 & .00 & 4.18 & 4.18 & 2.97 & 7.15 \\
\hline Wahkiakum & .07 & .00 & .00 & .07 & .07 & .00 & .07 \\
\hline Walla Walla & .82 & 15.5 & .00 & 16.3 & 16.3 & 1.08 & 17.4 \\
\hline Whatcom & .00 & 7.33 & .00 & 7.33 & 7.33 & 31.5 & 38.8 \\
\hline Whitman & .00 & .00 & .00 & .00 & .00 & .03 & .03 \\
\hline Yakima & 6.51 & .00 & .00 & 6.51 & 6.51 & 6.68 & 13.2 \\
\hline State & 138 & 439 & 39.9 & 577 & 617 & 63.5 & 681 \\
\hline
\end{tabular}




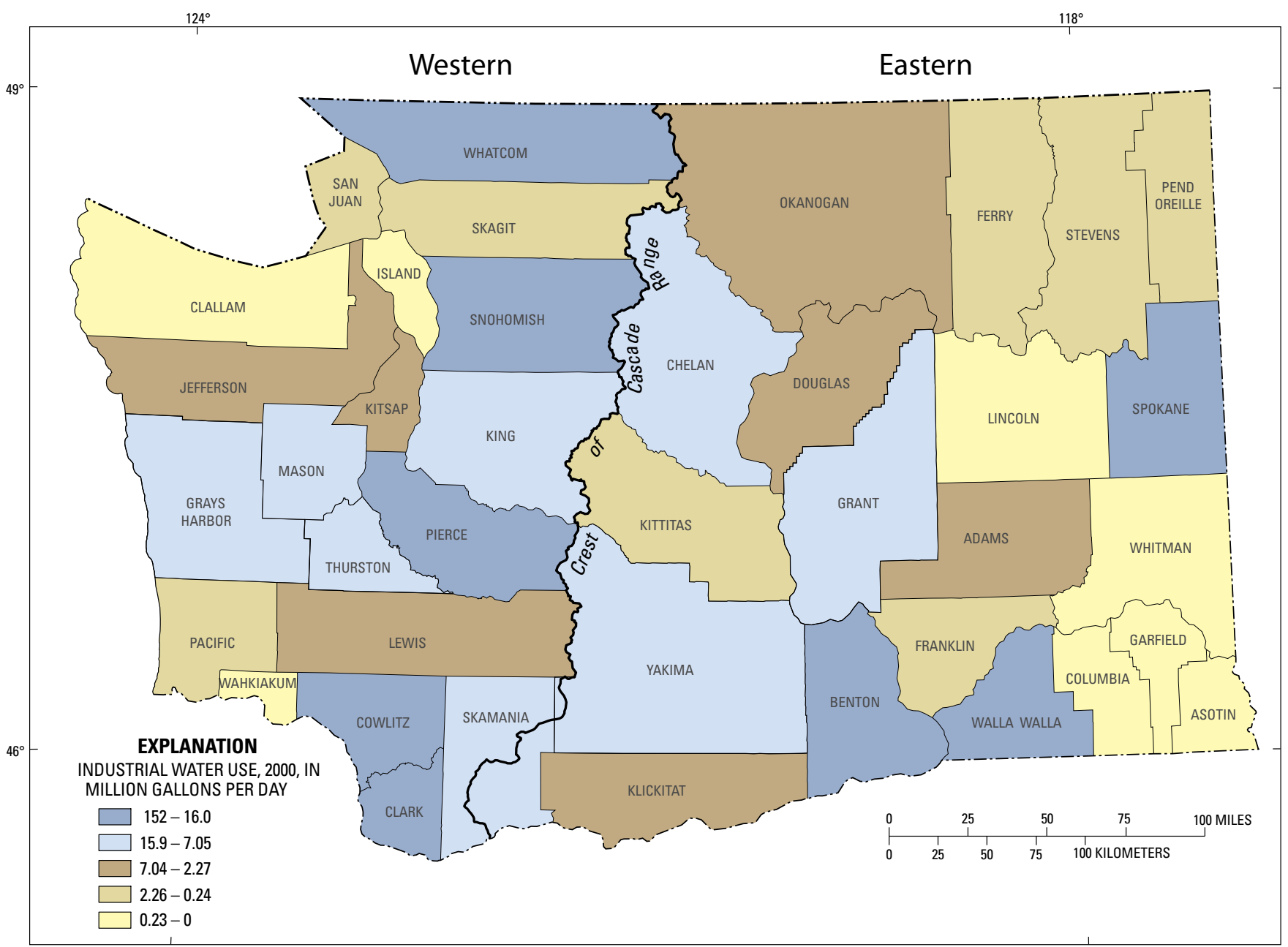

Figure 7. Estimated industrial water use in Washington, 2000.

Industrial water use in eastern Washington was estimated to be $193 \mathrm{Mgal} / \mathrm{d}$, or 28 percent of the total State use. Public water-supply systems delivered 9 percent $(17.7 \mathrm{Mgal} / \mathrm{d})$ of the regional use. Self-supplied fresh ground water accounted for 21 percent (41.4 Mgal/d), and self-supplied fresh surface water was estimated to be 70 percent ( $134 \mathrm{Mgal} / \mathrm{d})$. The largest industrial withdrawals in eastern Washington were in Benton, Spokane, Walla Walla, and Chelan Counties. These four counties accounted for 70 percent $(152 \mathrm{Mgal} / \mathrm{d})$ of the regional industrial use and 22 percent of the State total industrial water use.
Industrial water-use data for Washington have not been collected in a comprehensive manner since 1985. Since then, the USGS in Washington has generated estimates of industrial water use using changes in industrial hours as reported by the U.S. Department of Commerce. The estimates of self-supplied industrial water use in 2000 are based on similar estimates from the USGS 1995 Water Use Compilation that were modified on the basis of changes in the number of industrial hours worked between 1992 and 1997 (U.S. Department of Commerce, 1998). The estimate of public-supplied industrial water use is based on data from the USGS inventory of selected publicwater-supply systems discussed in the section "Domestic Water Use." 


\section{SUMMARY}

In the year 2000, domestic water use in Washington was estimated to be $674 \mathrm{Mgal} / \mathrm{d}$ (million gallons per day), with an estimated per-capita rate of $114 \mathrm{gal} / \mathrm{d}$ (gallons per day). Domestic per-capita rates at the county level ranged from 87 to $238 \mathrm{gal} / \mathrm{d}$. For western Washington, domestic water use was estimated to be $445 \mathrm{Mgal} / \mathrm{d}$, the regional per-capita rate was estimated to be $97 \mathrm{gal} / \mathrm{d}$, and county per-capita rates ranged from 87 to $158 \mathrm{gal} / \mathrm{d}$. For eastern Washington, domestic water use was estimated to be $229 \mathrm{Mgal} / \mathrm{d}$, the regional per-capita rate was estimated to be $175 \mathrm{gal} / \mathrm{d}$, and the county per-capita rates ranged from 102 to $238 \mathrm{gal} / \mathrm{d}$.

Crop-irrigation water use in Washington was estimated to be 3,365 thousand acre-ft (3,005 Mgal/d), with an estimated application rate of 2.2 acre-feet per acre per year, or feet per year (ft/yr). For western Washington, the application rate was estimated to be $1.2 \mathrm{ft} / \mathrm{yr}$, and the county rates ranged from 0.3 to $1.9 \mathrm{ft} / \mathrm{yr}$. For eastern Washington, the estimated application rate was $2.2 \mathrm{ft} / \mathrm{yr}$, and the county application rates ranged from 0.6 to $3.2 \mathrm{ft} / \mathrm{yr}$.

Golf-course irrigation water use in Washington was estimated to be 26.5 thousand acre-ft $(23.6 \mathrm{Mgal} / \mathrm{d})$, with an estimated application rate of $1.4 \mathrm{ft} / \mathrm{yr}$. For western Washington, the application rate was estimated to be $1.2 \mathrm{ft} / \mathrm{yr}$, and the county rates ranged from 0.3 to $2.0 \mathrm{ft} / \mathrm{yr}$. For eastern Washington, the estimated application rate was $1.8 \mathrm{ft} / \mathrm{yr}$, and the county application rates ranged from 0.6 to $3.2 \mathrm{ft} / \mathrm{yr}$.

Industrial water use in Washington was estimated to be $681 \mathrm{Mgal} / \mathrm{d}$. Industrial water use in western Washington was estimated to be $488 \mathrm{Mgal} / \mathrm{d}$, or 77 percent of the State industrial use. Industrial water use in eastern Washington was estimated to be $193 \mathrm{Mgal} / \mathrm{d}$, or 28 percent of the State total.

Water use in Washington has evolved in the past century from meager domestic and stock water needs to the current complex requirements of domestic water users, large irrigation projects, industrial plants, fish habitat, and recreation. Historically, domestic, irrigation, and industrial water use account for about 92 percent estimated offstream water use in Washington. Although advances have been made in the ability to control, divert, and develop water supplies, insufficient effort has gone into keeping accurate and complete records of the actual amounts of water being used. With increasing competition for water, water-use information is of considerable value in determining water availability and in making sound resource management decisions. Although the State of Washington has begun to collect water-use information in selected basins, there is currently no statewide program requiring the reporting of water-use information to the State.

\section{SELECTED REFERENCES}

Dion, N.P., 1985, Washington ground-water resources, in U.S. Geological Survey, 1985, National Water Summary 1984: Hydrologic events, selected water-quality trends, and ground-water resources: U.S. Geological Survey WaterSupply Paper 2275, p. 433-438.

U.S. Department of Agriculture, 1997, 1997 census of agriculture: National Agricultural Statistics Service, accessed May 21, 2001, at http://www.nass/usda.gov/census/census97/volume1/wa-47.

U.S. Department of Agriculture,1998, 1998 farm and ranch irrigation survey: National Agricultural Statistics Service, accessed May 21, 2001, at http://www.nass.usda.gov/census/ census $97 /$ frisaq.

U.S. Department of Commerce, 1998, 1997 census of manufactures, MC97-A-48, Geographic Area Series: Washington: accessed July 30, 2001, at http://www.census.gov/epcd/ www/97EC31.htm.

U.S. Department of Commerce, 2001, population census 2000: Bureau of the Census, accessed May 16, 2001, at http://factfinder.census.gov/servlet/Basic FactsTable.

Washington State Department of Health, 2001, Public Water Systems data base: Washington State Department of Health data available on the Web, accessed January 10, 2001, at http://ww3/doh.wa.gov/sadie.

Williams, J.R., 1986, Washington surface-water resources, in Moody, D.E., Chase, E.B., and Aronson, D.A., 1986, National Water Summary 1985: Hydrologic events and surface-water resources: U.S. Geological Survey Water-Supply Paper 2300, p. 473-478.

\section{U.S. Geological Survey Water-Use Reports [in order of date published]}

MacKichan, K.A., 1951, Estimated water use in the United States-1950: U.S. Geological Survey Circular $115,13 \mathrm{p}$.

MacKichan, K.A., 1957, Estimated water use in the United States, 1955: U.S. Geological Survey Circular 398,18 p. 
MacKichan, K.A., and Kammerer, J.C., 1961, Estimated water use in the United States, 1960: U.S. Geological Survey Circular 456, 44 p.

Laird, L.B., and Walters, K.L., 1967, Municipal, industrial, and irrigation water use in Washington, 1965: U.S. Geological Survey Open-File Report, 13 p.

Murray, C.R., 1968, Estimated water use in the United States, 1965: U.S. Geological Survey Circular 556, 53 p.

Parker, G.G., 1971, Municipal, industrial, and irrigation water use in Washington, 1970: U.S. Geological Survey Open-File Report, $21 \mathrm{p}$.

Murray, C.R., and Reeves, E.B., 1972, Estimated water use in the United States in 1970: U.S. Geological Survey Circular $676,37 \mathrm{p}$.

Murray, C.R., and Reeves, E.B, 1977a, Estimated water use in the United States in 1975: U.S. Geological Survey Circular $765,39 \mathrm{p}$.

Dion, N.P., and Lum, W.E., II., 1977b, Municipal, industrial, and irrigation water use in Washington, 1975: U.S. Geological Survey Open-File Report 77-308, 34 p.

Solley, W.B., Chase, E.B., and Mann, W.B., IV., 1983, Estimated use of water in the United States in 1980: U.S. Geological Survey Circular 1001, 56 p.

Solley, W.B., Merk, C.F., and Pierce. R.R., 1988, Estimated use of water in the United States in 1985: U.S. Geological Survey Circular 1004, 82 p.

Solley, W.B., Pierce, R.R., and Perlman, H.A., 1993, Estimated use of water in the United States in 1990: U.S. Geological Survey Circular 1081, 76 p.

U.S. Geological Survey, 1997a, Estimated water use in Washington, 1985: U.S. Geological Survey data available on the Web, accessed January 10, 2001, at http://wa.water.usgs. gov/data/wuse/main.cnty.85.txt.

U.S. Geological Survey, 1997b, Estimated water use in Washington, 1990: U.S. Geological Survey data available on the Web, accessed January 10, 2001, at http://wa.water.usgs. gov/data/wuse/main.cnty.90.txt.
U.S. Geological Survey, 1997c, Estimated water use in Washington, 1995: U.S. Geological Survey data available on the Web, accessed January 10, 2001, at http://wa.water.usgs. gov/data/wuse/main.cnty.95.txt.

Solley, W.B., Pierce, R.R., and Perlamn, H.A., 1998, Estimated water use in the United States in 1995: U.S. Geological Survey Circular 1200, $71 \mathrm{p}$.

U.S. Geological Survey, 2003, Estimated water use in Washington, 2000: U.S. Geological Survey data available on the Web, accessed January 10, 2001, at http://wa.water.usgs.gov/data/ wuse/main.cnty.00.txt.

\section{APPENDIX A. CONCEPTS AND TERMS}

The concepts and terms in this appendix are modified from the U.S. Geological Survey's National Handbook of Recommended Methods for Water Data Acquisition, available on the Web at http://water.usgs.gov/pubs/chapter11/chapter11M. html, and from its guidelines for preparation of State water-use estimates.

Class A system-A public water-supply system that has a full-time service population of at least 25 people or that has at least 15 connections.

Class B system-A public water-supply system that has a full-time service population of less than 25 people or that has fewer than 15 connections.

Crop-irrigation water use is water that is applied by an irrigation system to sustain plant growth in all agricultural and horticultural vegetation. It also includes water that is applied for pre-irrigation, frost protection, chemical application, weed control, field preparation, crop cooling, harvesting, dust suppression, and for the leaching of salts from the root zone.

Domestic water use includes water used for household purposes such as drinking, food preparation, bathing, washing clothes and dishes, flushing toilets, car washing, and watering lawns and gardens. The largest components of domestic use can be inside household uses (bathing, flushing toilets, and so forth) or outside household uses (lawn and garden watering, car washing, and so forth), depending on the climate. Typically, the largest components of inside household use are toilet flushing (39 percent) and bathing (30 percent). Outside household uses range from near zero in humid areas to 60 percent of total domestic use in arid areas. Domestic water may come from a public water-supply system or be self supplied. 
Golf-course irrigation water use is water applied to public and private golf courses by an irrigation system to maintain the greens, tees, fairways, and other grass areas of the course.

Industrial water use includes total fresh and saline withdrawals from ground and surface sources that are used for fabrication, processing, product washing, cooling, plant cleaning, and other sanitary purposes by businesses engaged in the manufacturing or processing of products such as steel, chemical and allied products, paper and allied products, smelting, and petroleum refining. The category also includes water used to manufacture and package products, $\log$ trees, produce pulp and paper, publish written materials, refine petroleum, tan and finish leather, cut and process stone, smelt and refine metals including steel, among other things. The water may be obtained from a pubic supply or may be self supplied. See also public water-supply system and self-supplied water. The five major industrial groups that use the most water per facility are:

- Food and kindred products-the manufacture or processing of foods and beverages for human consumption and related products such as ice, vegetable and animal fats and oils, and prepared feeds for animals and fowls

- Paper and allied products - the manufacture of pulps from wood and fibers; the manufacture of paper and paperboard

- Chemicals and allied products-the production of chemicals and chemical products such as drugs, cosmetics, and soaps

- Petroleum refining and related industries-petroleum refining and the manufacture of paving materials, roofing materials, and lubricating oils and greases

- Primary metals industries-smelting and refining of ferrous and nonferrous metals from ore, pig, or scrap; alloying metals; manufacturing nails, spikes, and insulated wire and cable

Instream water use-Use of water while it remains in the stream (surface water) or aquifer (ground water). Instream uses include hydroelectric power generation, recreation, transportation, waste assimilation, aesthetics, cultural resource preservation, fish and wildlife preservation, biodiversity, wetlands preservation, freshwater dilution of saline estuaries, and maintenance of the riparian zone.

Municipal water system-A water-supply system owned by a governmental organization (such as a town or city), serving residential and non-residential users.
Non-crop irrigation water use is water used to irrigate parks, nurseries, turf farms, cemeteries, and other landscaped areas exclusive of golf courses. Non-crop irrigation is not included in this report.

Non-municipal water system-A water-supply system serving single-family homes with yards and gardens.

Offstream water use-Use of water that has been removed from a ground- or surface-water source. Offstream water use includes domestic and public-water supply, industry, irrigation, livestock, cooling for thermoelectric power generation, mining, and domestic purposes. Sometimes it is called off-channel or withdrawal use.

Other-A non-municipal water-supply system serving mobile home parks, apartment buildings, and resorts.

Public water-supply system-A public or privately owned facility that supplies water for use by cities, towns, water districts, mobile-home parks, Indian reservations, military bases, and other similar institutions. Water delivered by public systems may be ground water, surface water, or a mixture of both. The delivered water is used for a variety of uses, such as domestic, commercial, thermoelectric power, industrial, and public water use. In addition, some public-supplied water is used for water and wastewater treatment, public services such as pools, parks, and city buildings, or is lost through system leaks and maintenance.

Self-supplied water-Water withdrawn from a surfacewater or a ground-water source by a user and not obtained from a public supply.

Water use, in the broadest sense, pertains to the interaction of human activity with and its influence on the hydrologic cycle and includes elements such as self-supplied withdrawal, public-supply delivery, consumptive use, wastewater release, reclaimed wastewater, return flow, and instream use. In a restrictive sense, water use refers to water that is actually used for a specific purpose, such as for domestic use, irrigation, or industrial processing. Water use is divided into two types, offstream and instream use.

Withdrawal-The quantity of water removed from a ground-water source or diverted from a surface-water source to the point of use. 


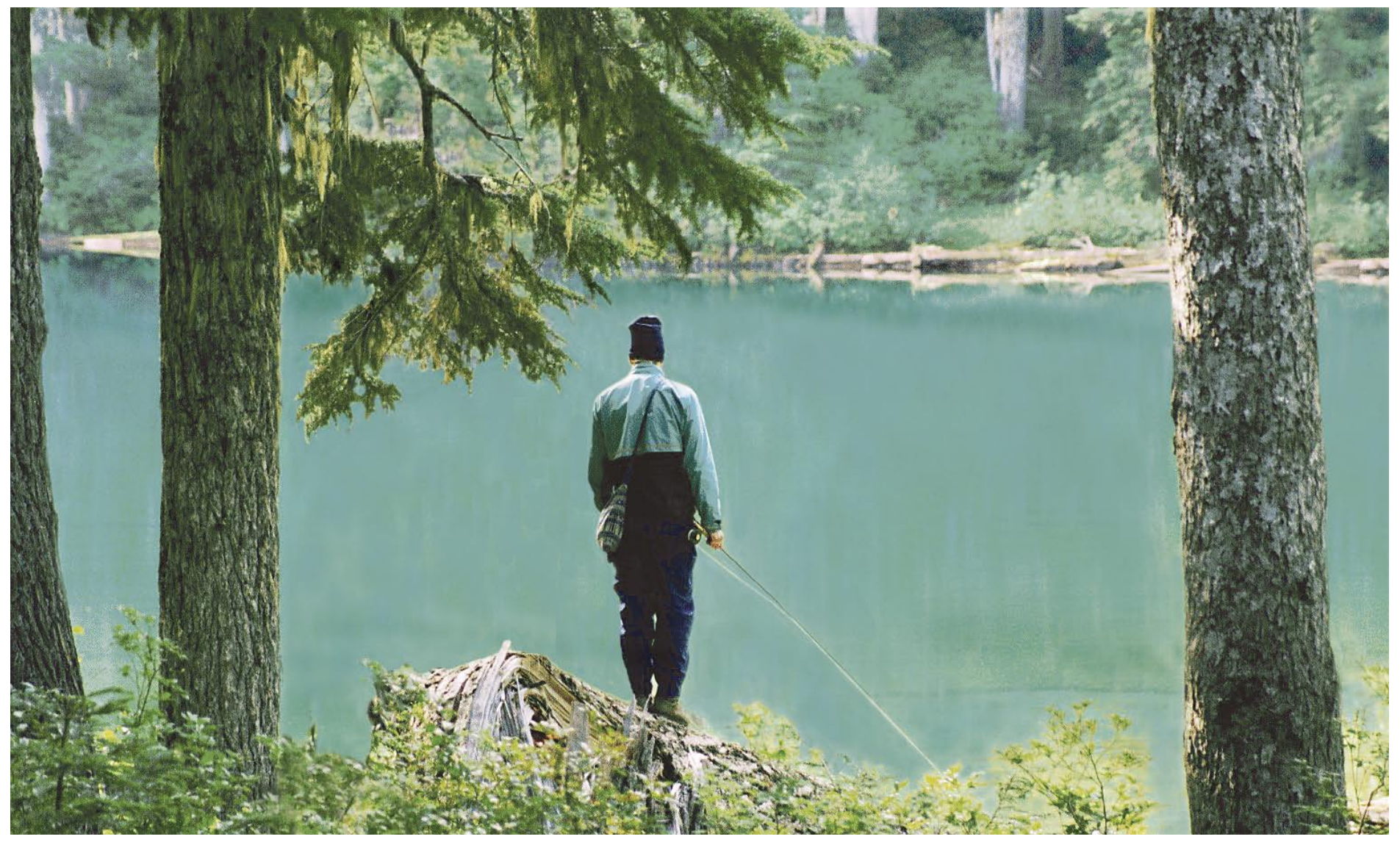

Water

Hoodsport in the Olympic National Park, Washington. (Photograph taken by Chad Flynn, Volunteer, U.S. Geological Survey, Sept. 18, 2002.)

\section{U.S. Department of the Interior Gale A. Norton, Secretary}

\section{U.S. Geological Survey Charles G. Groat, Director}

\section{U.S. Geological Survey, Reston, Virginia: 2004}

For sale by U.S. Geological Survey, Information Services Box 25286, Denver Federal Center Denver, CO 80225-0286

For more information about the USGS and its products: Telephone: 1-888-ASK-USGS

World Wide Web: http://www.usgs.gov/

Any use of trade, product, or firm names in this publication is for descriptive purposes only and does not imply endorsement by the U.S. Government

Although this report is in the public domain, permission must be secured from the individual copyright owners to reproduce any copyrighted materials contained within this report.

\section{Suggested citation:}

Lane, R.C., 2004, Estimated domestic, irrigation, and industrial water use in Washington, 2000: U.S. Geological Survey Scientific Investigations Report 2004-5015, 16 p.

Manuscript approved for publication, February 4, 2004

Prepared by the Publishing Group, U.S. Geological Survey, Washington Water Science Center, Tacoma, Washington USGS Publishing staff: Judith A. Wayenberg, Bob Crist, Bill Gibbs, David Holter

For more information concerning this report, contact the

Washington Water Science Center Director, U.S. Geological Survey, 1201 Pacific Avenue - Suite 600 Tacoma, Washington 98402

http://wa.water.usgs.gov 